\title{
Effects of high-fat feeding on ectopic fat storage and postprandial lipid metabolism in mouse offspring
}

Citation for published version (APA):

van Ewijk, P. A., Paglialunga, S. A., Kooi, M. E., Nunes, P. M., Gemmink, A., Slenter, J., Moonen Kornips, E., Jorgensen, J. A., Hoeks, J., Wildberger, J. E., Hesselink, M. K., Glatz, J. F., Heerschap, A., Kersten, S., Schrauwen, P., \& Schrauwen-Hinderling, V. B. (2015). Effects of high-fat feeding on ectopic fat storage and postprandial lipid metabolism in mouse offspring. Obesity, 23(11), 2242-2250.

https://doi.org/10.1002/oby.21235

Document status and date:

Published: 01/01/2015

DOI:

10.1002/oby.21235

Document Version:

Publisher's PDF, also known as Version of record

\section{Document license:}

Taverne

\section{Please check the document version of this publication:}

- A submitted manuscript is the version of the article upon submission and before peer-review. There can be important differences between the submitted version and the official published version of record.

People interested in the research are advised to contact the author for the final version of the publication, or visit the DOI to the publisher's website.

- The final author version and the galley proof are versions of the publication after peer review.

- The final published version features the final layout of the paper including the volume, issue and page numbers.

Link to publication

\footnotetext{
General rights rights.

- You may freely distribute the URL identifying the publication in the public portal. please follow below link for the End User Agreement:

www.umlib.nl/taverne-license

Take down policy

If you believe that this document breaches copyright please contact us at:

repository@maastrichtuniversity.nl

providing details and we will investigate your claim.
}

Copyright and moral rights for the publications made accessible in the public portal are retained by the authors and/or other copyright owners and it is a condition of accessing publications that users recognise and abide by the legal requirements associated with these

- Users may download and print one copy of any publication from the public portal for the purpose of private study or research.

- You may not further distribute the material or use it for any profit-making activity or commercial gain

If the publication is distributed under the terms of Article $25 \mathrm{fa}$ of the Dutch Copyright Act, indicated by the "Taverne" license above, 


\title{
Effects of High-Fat Feeding on Ectopic Fat Storage and Postprandial Lipid Metabolism in Mouse Offspring
}

\author{
Petronella A. van Ewijk ${ }^{1,2,3}$, Sabina Paglialunga ${ }^{1,3}$, M. Eline Kooi ${ }^{2,3,4}$, Patricia M. Nunes ${ }^{5}$, Anne Gemmink ${ }^{3,6}$, Jos Slenter ${ }^{2}$, \\ Esther Kornips $^{1,3}$, Johanna A. Jörgensen ${ }^{1,3}$, Joris Hoeks ${ }^{1,3}$, Joachim E. Wildberger ${ }^{2,4}$, Matthijs K.C. Hesselink ${ }^{3,6}$, \\ Jan F.C. Glatz ${ }^{4,7}$, Arend Heerschap ${ }^{5}$, Sander Kersten ${ }^{8,9}$, Patrick Schrauwen $^{1,3}$, and Vera B. Schrauwen-Hinderling ${ }^{2,3}$
}

Objective: Parental high-fat feeding was proposed to negatively impact metabolic health in offspring. Here, the ectopic fat storage in heart and liver in offspring was investigated, and the effects on mitochondrial function, de novo lipogenesis, and postprandial lipid metabolism were explored in detail.

Methods: Male and female mice received either a high-fat (HF) or standard chow (LF) diet during mating, gestation and lactation. All offspring animals received the HF diet.

Results: Abdominal visceral adipose tissue tended to be higher in HF/HF mice. Cardiac lipid content was also higher in the HF/HF mice (LF/HF vs. HF/HF: $1.03 \% \pm 0.08 \%$ vs. $1.33 \% \pm 0.07 \%$ of water signal, $P=0.01)$. In contrast, hepatic lipid content tended to be lower in HF/HF mice compared to LF/HF mice. A severely disturbed postprandial lipid clearance was revealed in $\mathrm{HF} / \mathrm{HF}$ mice by the results from the triglyceride (TG) tolerance tests (LF/HF vs. HF/HF: $6,753 \pm 2,213$ vs. $14,367 \pm 1,978 \mathrm{mmol} \mathrm{I}^{-1} \mathrm{~min}^{-1}$, $P=0.01$ ) and ${ }^{13} \mathrm{C}$-fatty acid retention test (LF/HF vs. HF/HF: $2.73 \% \pm 0.85 \%$ vs. $0.89 \% \pm 0.26 \%$ retention from bolus, $P=0.04$ ), which may underlie the lower hepatic lipid content.

Conclusions: Here it is shown that HF diet negatively impacts postprandial TG clearance in offspring and results in an overall metabolic unfavorable phenotype and ectopic lipid deposition in the heart and in visceral storage sites.

Obesity (2015) 23, 2242-2250. doi:10.1002/oby.21235

\section{Introduction}

In spite of large-scaled efforts to promote a healthy body weight, the prevalence of obesity and metabolic syndrome is still rising (1), thereby increasing the risk for diabetes (2) and cardiovascular disease. It is unresolved to what extent this dramatic increase is accounted for by changed dietary habits. An underestimated factor that may exacerbate the effects of an unhealthy lifestyle may be the presence of obesity in the previous generation. There is evidence for a carry-over effect from one generation to the next. For instance, positive relationships between maternal pregravid BMI and birthweight (3), fetal insulin resistance (4), and fetal body fat percentage have been reported (5). Moreover, children of mothers with obesity have increased risk to develop metabolic syndrome (6) and congenital heart defects (7). More specifically, in non-human primates it was found that maternal exposure to a high-fat diet (31.6 energy\%) resulted in a metabolic syndrome phenotype in $60 \%$ of the offspring and increased the risk for non-alcoholic fatty liver disease (NAFLD) (8). It also was shown in a rodent model that increasing the dietary fat content during pregnancy and lactation suffices to adversely affect the offspring in terms of promoting hepatic lipid storage and inflammation and diminishing markers of mitochondrial function and de novo lipogenesis (9). When examining lipid metabolism, most studies are limited to the investigation of fasted concentrations of plasma metabolites. However, postprandial lipid metabolism is also an important player in mediating

\footnotetext{
${ }^{1}$ Department of Human Biology, Maastricht University, Maastricht, The Netherlands ${ }^{2}$ Department of Radiology, Maastricht University Hospital, Maastricht, The Netherlands. Correspondence: Vera B. Schrauwen-Hinderling (v.schrauwen@maastrichtuniversity.nl) ${ }^{3}$ NUTRIM—School for Nutrition, Toxicology and Metabolism, Maastricht, The Netherlands ${ }^{4}$ CARIM-Cardiovascular Research Institute Maastricht, Maastricht, The Netherlands ${ }^{5}$ Department of Radiology, Radboud University Medical Centre, Nijmegen, The Netherlands ${ }^{6}$ Department of Human Movement Sciences, Maastricht University, Maastricht, The Netherlands ${ }^{7}$ Department of Molecular Genetics, Maastricht University, Maastricht, The Netherlands ${ }^{8}$ Department of Nutrition, Metabolism and Genomics Groups, Division of Human Nutrition, Wageningen University, Wageningen, The Netherlands ${ }^{9}$ Netherlands Nutrigenomics Centre, Top Institute Food and Nutrition, Wageningen, The Netherlands.
}

Funding agencies: P. Schrauwen is supported by a VICl (grant 918.96.618) for innovative research from the Netherlands Organization for Scientific Research (NWO). V.B. Schrauwen-Hinderling is supported by a VENI (grant 91611136) for innovative research from NWO. M.E. Kooi is supported by Aspasia Grant 015.008 .047 from NWO. This research was performed within the framework of CTMM, the Center for Translational Molecular Medicine (www.ctmm.nl), project PREDICCt (grant 01C-104), and supported by the Dutch Heart Foundation, Dutch Diabetes Research Foundation, and Dutch Kidney Foundation.

Disclosure: The authors declared no conflict of interest.

Additional Supporting Information may be found in the online version of this article.

Received: 17 April 2015; Accepted: 23 June 2015; Published online 4 November 2015. doi:10.1002/oby.21235 
metabolic risk, which is not necessarily reflected in fasted plasma concentrations. We therefore investigated how the postprandial response to a lipid load is modified in offspring of high-fat-fed mice. We investigated the effect on muscle, cardiac, and hepatic steatosis and function using non-invasive techniques. We report that offspring of mice that were exposed to an obesogenic high-fat diet have increased visceral adipose tissue (VAT) mass and increased cardiac lipid content, while hepatic lipid content tended to be lower due to delayed postprandial clearance of dietary triglyceride (TG).

\section{Methods}

\section{Animal model and study set up}

The Institutional Ethics Committee on Animal Welfare approved all experiments. C57B1/6 mice (breeding couples from Charles River) were housed under standard conditions at $25^{\circ} \mathrm{C}$ with a $12: 12$-h lightdark cycle with ad libitum access to water and diet. Mice were randomly assigned to either a high-fat (HF) diet $(45 \% \mathrm{kcal}$ fat of which $31 \%$ saturated, $36 \%$ mono-unsaturated, 33\% poly-unsaturated fatty acids, $20 \% \mathrm{kcal}$ protein, $35 \% \mathrm{kcal}$ carbohydrate, Research Diets, New Brunswick, NJ) or standard chow (LF) diet (9\% kcal fat, 33\% kcal protein, $58 \%$ kcal carbohydrate, ssniff Spezialdiäten $\mathrm{GmbH}$ ). Mice were fed their assigned diet at least 6 weeks before mating and the diet was continued during gestation and lactation. Weight gain and food intake were measured weekly (Supporting Information Figure S1). Littersize was similar in both groups. At weaning, all offspring was fed the HF diet, generating two experimental groups: $\mathrm{HF} / \mathrm{HF}$ and $\mathrm{LF} / \mathrm{HF}$. Body weight and food intake was determined each week and was similar in both groups (Supporting Information Figure S2). Measurements were only performed in male offspring, because of the possibility of sexual dimorphism. Male offspring ( $n=13$ from each group) underwent a glucose tolerance test (GTT) at 12 weeks of age, and cardiac function and cardiac -, hepatic - and abdominal visceral fat was measured at 15 weeks of age. In a parallel group of mice, cardiac and hepatic mitochondrial function was determined at 12 weeks of age.

A third, parallel group of male offspring ( $n=9 \mathrm{HF} / \mathrm{HF}$ and $n=9 \mathrm{LF} /$ $\mathrm{HF}$ ) underwent a triglyceride tolerance test (TTG) at 10 weeks of age and cardiac and hepatic lipid retention and de novo lipogenesis (DNL) was measured at 12 weeks of age. The study design is also presented in the Supporting Information Figure S3. Changes in ectopic fat deposition during early adulthood (around 15 weeks) have been reported before in mice when the previous generation was exposed to HF feeding (9). To study underlying mechanisms, we performed detailed measurements in mice around 10-15 weeks of age.

\section{Magnetic resonance imaging and spectroscopy in vivo}

Cardiac function, cardiac-, hepatic-, and abdominal visceral fat content were measured using magnetic resonance imaging (MRI) and spectroscopy (MRS). Mice were anesthetized with 2\% isoflurane and $0.41 \mathrm{~min}^{-1}$ of $\mathrm{O}_{2}$ and placed in a cradle with warm waterbed, in a quadrature volume coil ( $\varnothing 35 \mathrm{~mm}$, transmit-receive, Bruker Biospin) of 7 Tesla MR System (Bruker Biospin GmbH, Ettlingen, Germany).

\section{Visceral fat content}

Coronal T1-weighted spin-echo images (matrix size: $256 \times 256$, FOV: $50 \times 50 \mathrm{~mm}^{2}$, TE: $9.1 \mathrm{~ms}$, TR: $500 \mathrm{~ms}$, NA: 1 , slice thick- ness: $1 \mathrm{~mm}$ ) were obtained. Using in-house developed software, VAT content was determined in the three-dimensional region from the middle of the left kidney to the middle of the bladder. Images were checked individually and manually edited in MRIcron (10).

\section{Cardiac and hepatic lipid content assessed by ${ }^{1} \mathrm{H}-\mathrm{MRS}$}

Cardiac ${ }^{1} \mathrm{H}-\mathrm{MRS}$ was performed using cardiac-triggered and respiratory-gated point resolved spectroscopy (PRESS, TE $=9.1 \mathrm{~ms}$, $\mathrm{TR}=2,000 \mathrm{~ms}$ ). Spectra were acquired from a $4-\mu \mathrm{l}$ voxel in the interventricular septum. A water-suppressed spectrum was acquired $(\mathrm{NSA}=512)$ as well as a reference spectrum (with non-suppressed water signal, NSA $=64)$. Spectra were fitted using the AMARES algorithm in jMRUI (11). The sum of the TG peaks at 1.55, 1.26, and $0.85 \mathrm{ppm}$ was expressed as percentage of the unsuppressed water signal.

Hepatic lipid content was determined as described for cardiac lipid, but with a water-suppressed spectrum $(\mathrm{NSA}=128)$ and water spectrum $(\mathrm{NSA}=64)$ from a $18-\mu$ l voxel.

\section{Cardiac function assessed by MRI}

Bright blood cine images in four-chamber view $(4 \mathrm{CH})$, long axis view (LA), and two slices of short axis view (SA) were acquired [1$2 \mathrm{~mm}$ under the mitral valve and at the base of the papillary muscle were acquired as described before (12)]. End-diastolic volume (EDV), end-systolic volume (ESV), and ejection fraction (EF) were calculated using the modified Simpson Rule (12).

\section{Glucose tolerance test, plasma insulin, and plasma metabolites}

Mice were fasted for $6 \mathrm{~h}$ and injected intraperitoneally with glucose ( $2 \mathrm{mg} \mathrm{g}^{-1}$ body weight in $200 \mu \mathrm{l}$ of sterile solution) as reported earlier (13).

Fasting plasma insulin levels were determined using a Meso Scale Discovery (MSD) assay (Gaithersburg, USA) and HOMA index was calculated. At 12 weeks of age, venous blood was collected in EDTA-containing tubes $\left(1 \mathrm{mg} \mathrm{ml}^{-1}\right)$ after a 5 -h fast and plasma TG and NEFA levels were determined (Roche, Schlieren, Switzerland and Wako Chemicals, Neuss, Germany, respectively).

\section{Biochemical TG determination in gastrocnemicus}

TG levels in gastrocnemius muscle were measured using the method of Schwartz and Wolins (14).

\section{Mitochondrial isolation and respiration measurements}

Mice were anaesthetized and killed by decapitation. Mitochondria were isolated as previously described with minor modifications (15). Briefly, heart and liver were excised and placed in ice-cold isolation buffer, rinsed, and minced on ice. Heart tissue was further digested with an enzymatic treatment (protease, Sigma). After homogenation and centrifugation, the resulting pellet was re-suspended in isolation buffer (HIB for heart and LIB without BSA for liver preparations) and centrifuged in two steps (at $800 \mathrm{~g}$ and $8,500 \mathrm{~g}$ at $4^{\circ} \mathrm{C}$ ). The final mitochondrial pellet was resuspended in HIB and homogenized. Mitochondrial protein content was 
determined by Fluram assay (15). Mitochondrial respiration (heart: 0.1 $\mathrm{mg} \mathrm{ml}{ }^{-1}$ and liver: $0.25 \mathrm{mg} \mathrm{ml}^{-1}$ ) was determined at $37^{\circ} \mathrm{C}$ in a twochamber Oxygraph (OROBOROS ${ }^{\circledR}$ Instruments, Innsbruck, Austria) using pyruvate $(5 \mathrm{mM})$ plus malate $(3 \mathrm{mM})$ for heart or glutamate $(5 \mathrm{mM})$ plus malate $(3 \mathrm{mM})$ for liver and palmitoyl-coenzyme A (CoA) $(50 \mu \mathrm{M})$ plus carnitine $(2 \mathrm{mM})$ as substrates. ADP $(450 \mu \mathrm{M})$ and oligomycin $\left(1 \mu \mathrm{g} \mathrm{ml}^{-1}\right)$ were added to obtain state 3 and state 4 respirations, respectively.

\section{Mitochondrial DNA and copy number}

Mitochondrial DNA copy number was determined by the ratio of COX2 expression over UCP2 expression as described previously (16).

\section{Hepatic de novo lipogensis}

Fractional contribution of DNL to the hepatic lipid pool was determined using ${ }^{1} \mathrm{H} /{ }^{2} \mathrm{H}$ NMR spectroscopy of liver extracts after ${ }^{2} \mathrm{H}_{2} \mathrm{O}$ enrichment (Sigma-Aldrich, St Louis, MO) as described before (17). Total hepatic TG and DNL fraction were quantified against pyrazine. The ratio between ${ }^{2} \mathrm{H}$ enriched body-water and the ${ }^{2} \mathrm{H}$ enrichment of hepatic TG methyl hydrogens determines the contribution of DNL to the total hepatic TG pool (18).

\section{Cardiac and hepatic lipid retention}

To determine the contribution of dietary fat to myocardial and hepatic TG, mice were fasted for $4 \mathrm{~h}$ and given an oral load of $\left[\mathrm{U}-{ }^{13} \mathrm{C}\right]$ algal-lipid mixture (Cambridge Isotope Laboratories, Andover, MA, $5 \mathrm{~g} \mathrm{~kg}^{-1}$ body weight). Four hours later, animals were killed and hearts and livers were freeze-clamped and lipids were extracted and analyzed by proton-decoupled ${ }^{13} \mathrm{C}$-NMR spectra of cardiac and hepatic lipids as described before (17).

Dietary lipid absorption to heart or liver ( $\%$ of bolus) is given as $=$

$\frac{\text { total cardiac or hepatic TG }(\mu \mathrm{mol} \cdot \mathrm{g}-1) \times 13 \mathrm{C} \text {-enrichment }(\%) \times \text { heart or liver weight }(\mathrm{g})}{\text { oral lipid } \operatorname{supply}(\mu \mathrm{mol})}$

\section{Triglyceride tolerance test}

Mice were shortly fasted $(4 \mathrm{~h})$ and received an oral bolus of olive oil $\left(11 \mathrm{~g} \mathrm{~kg}^{-1}\right)$. Plasma TG was assessed every hour for the next $4 \mathrm{~h}$ with a standard TG meter (Cardiocheck, Belgium).

\section{mRNA expression of LPL and modulators of LPL in hepatic and white adipose tissue}

For analyses of mRNA of LPL, ANGPTL4, GPIHBP1, and PPAR $\gamma$ in mouse white adipose tissue (WAT) and mRNA of hepatic lipase, ANGPTL4, ANGPTL3, apoE, and apoC3 in liver tissue, total RNA was isolated with TRIzol reagent (Invitrogen, Breda, The Netherlands) according to manufacturer's instructions. One $\mu \mathrm{g}$ of total RNA was reverse transcribed using iScript (Bio-Rad, Veenendaal, The Netherlands). cDNA was PCR-amplified with Platinum Taq DNA polymerase (Invitrogen) on a Bio-Rad CFX384 Real Time System using Sensimix (Bioline, GC Biotech, Alphen aan de Rijn, The Netherlands). Ribosomal protein 36B4 mRNA served as control. PCR primer sequences (PrimerBank) were ordered from Eurogentec (Seraing, Belgium).

\section{Statistical analysis}

Results are expressed as means \pm standard error of the mean (SEM). Statistical analysis was performed using IBM SPSS Statistics for Windows, Version 20.0 (Armonk, NY: IBM Corp). To evaluate effects between the two experimental groups, a two-tailed Student's t-test was used. Significance was set at $P \leq 0.05$.

\section{Results}

\section{Body weight, organ weight, and visceral fat content}

Body weight tended to be increased at 12 weeks of age (LF/HF vs. $\mathrm{HF} / \mathrm{HF}: 25.5 \pm 0.7$ vs. $27.3 \pm 0.7 \mathrm{~g}, P=0.08)$ in $\mathrm{HF} / \mathrm{HF}$ mice from group 1. VAT volume, also tended to be higher (LF/HF vs. HF/HF: $581.9 \pm 33.8$ vs. $881.2 \pm 106.7 \mu \mathrm{l}, P=0.08$, Figure 1$)$. No difference in heart or liver weight was observed.

\section{Fasted plasma metabolites and glucose tolerance test}

Fasted plasma glucose, insulin, plasma TG and NEFA levels were similar in both dietary groups (Table 1). Therefore, HOMA-IR was also similar. Early exposure to a HF diet did not change glucose tolerance (Figure 2).

\section{Skeletal muscle lipid content}

Skeletal muscle lipid content was not affected by early exposure to a $\mathrm{HF}$ diet (LF/HF vs. HF/HF: $0.015 \pm 0.002$ vs. $0.012 \pm 0.002$ TG $\mu \mathrm{l}^{-1}$ protein, $\left.P=\mathrm{ns}\right)$.

\section{Cardiac function, lipid content, and mitochondrial respiration}

Early exposure to a HF diet resulted in significantly increased cardiac lipid content at 15 weeks of age (LF/HF vs. $\mathrm{HF} / \mathrm{HF}: 1.03 \% \pm 0.08 \%$ vs. $1.33 \% \pm 0.07 \%$ of water signal, $P=0.01$, Figure 3 ). To investigate if changes in cardiac lipid content were associated with alterations in mitochondrial oxidative capacity, mitochondrial respiration was measured in isolated mitochondria in parallel groups. Prenatal exposure to the HF diet did not result in alterations in pyruvate or palmitoylCoA+ carnitine-supported respiration or mitochondrial copy number at 12 weeks of age. These differences in cardiac lipid content furthermore did not translate into differences in cardiac systolic function (EDV, ESV and EF, Supporting Information Figure S4). 

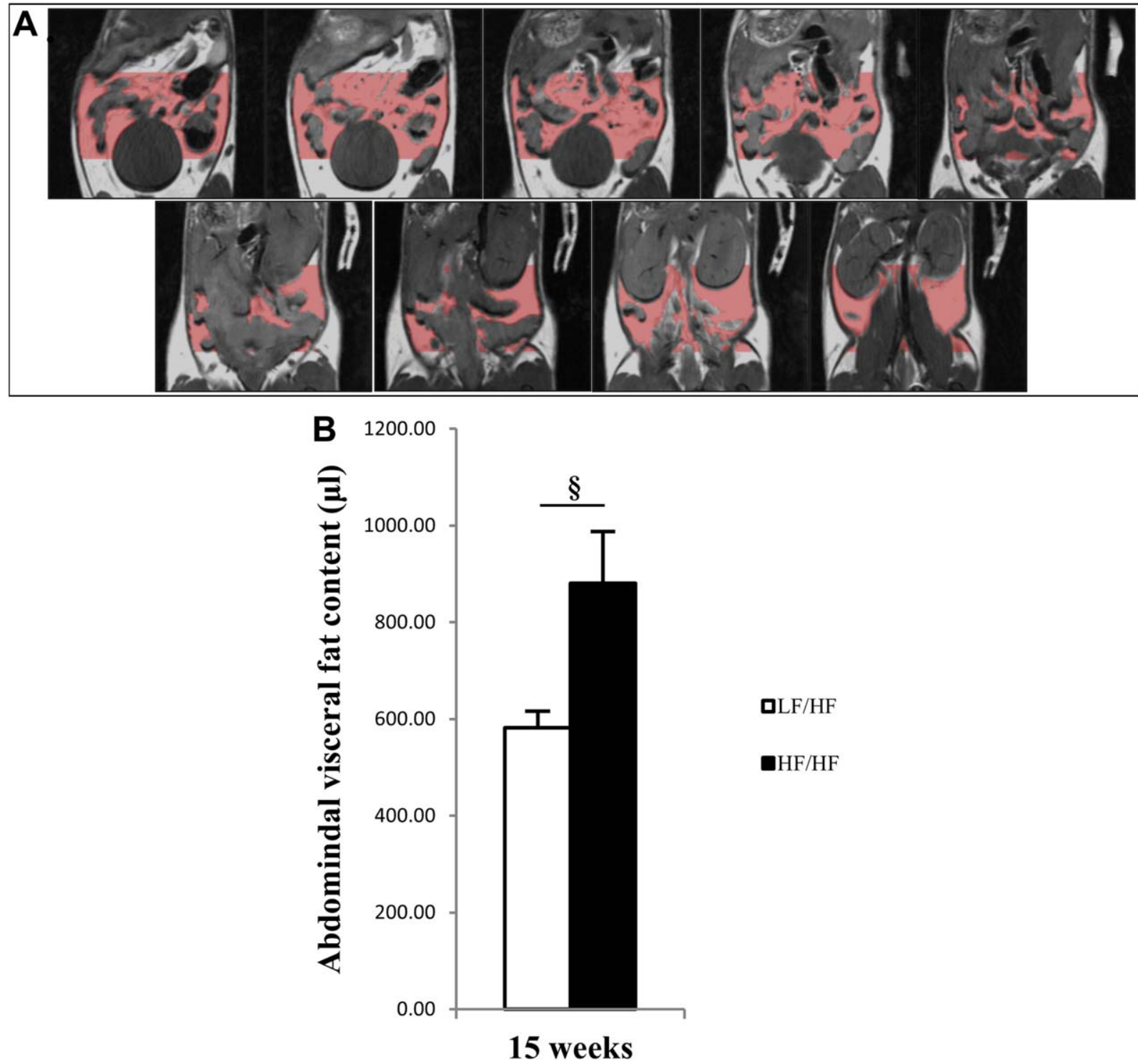

Figure 1 (A) Abdominal VAT was determined in the three-dimensional region from half the size of the left kidney to half the size of the bladder (from left to right, from top to bottom). (B) Mean ( \pm SEM) abdominal visceral fat content ( $\mu$ l) per group. A tendency for differences in VAT content between the groups is indicated with $\S P \leq 0.1$. [Color figure can be viewed in the online issue, which is available at wileyonlinelibrary.com.]

\section{Hepatic lipid content and mitochondrial function}

To investigate if similar effects are found in liver, hepatic lipid content was determined using ${ }^{1} \mathrm{H}-\mathrm{MRS}$. Typical spectra are shown in Figure 4. In contrast to the elevated lipid content in the heart, hepatic fat content tended to be reduced in mice exposed early to $\mathrm{HF}$ at 15 weeks of age ( $\mathrm{LF} / \mathrm{HF}$ vs. $\mathrm{HF} / \mathrm{HF}: 4.50 \% \pm 0.43 \%$ vs. $3.64 \% \pm 0.18 \%$ of water signal, $P=0.07$ ). These results were confirmed by ex vivo analysis of hepatic fat content in a parallel group of mice killed at 12 weeks of age (LF/HF vs. HF/HF: $271.67 \pm 49.21$ vs. $169.07 \pm 16.18 \mu \mathrm{mol} \mathrm{g}^{-1}$ of liver, $P=0.06$ ). Despite the reduced hepatic fat content in young mice, mitochondrial respiration on glutamate was significantly reduced in mice exposed early to the HF diet at 12 weeks of age (State 3: $1125 \pm 96$ vs. $\left.902 \pm 41 \mathrm{pmol}(\mathrm{s} \times \mathrm{mg})^{-1}, P=0.05\right)$. No differences in mito- chondrial respiration with palmitoylCoA as a substrate were observed between groups, and mitochondrial DNA copy number was not affected by early exposure to the HF diet (Table 2).

\section{Postprandial lipid handling and de novo lipogenesis}

As both cardiac and hepatic lipid content may be affected by dietary fat handling, we first investigated cardiac and hepatic dietary lipid retention. Cardiac lipid retention was similar in both groups (LF/HF vs. $\mathrm{HF} / \mathrm{HF}: 0.21 \% \pm 0.06 \%$ vs. $0.20 \% \pm 0.07 \%$ of bolus, NS, Figure $5 \mathrm{~A})$. However, early exposure to a HF diet resulted in a marked 3.1 fold reduction of hepatic lipid retention after a meal (LF/HF vs. HF/ HF: $2.73 \% \pm 0.85 \%$ vs. $0.89 \% \pm 0.26 \%$ retention from bolus, 

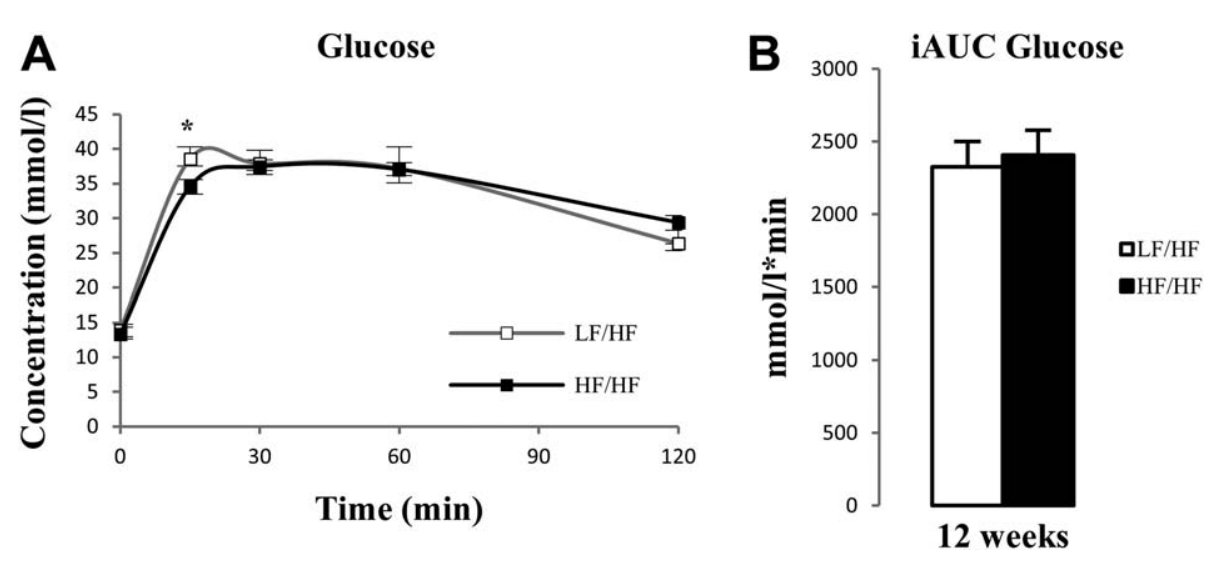

Figure 2 (A) Mean ( \pm SEM) plasma glucose concentrations during the glucose tolerance test. Only 15 min after the start of the IPGT, a significant difference in plasma glucose concentration was found, indicated with ${ }^{*} P \leq 0.05$. (B) Area under the curve (AUC) of the glucose concentration during the ipGTT. Glucose clearance was similar for the LF/HF and HF/HF mice.

$P=0.04$, Figure 5B). These results are consistent with a reduction in plasma TG clearance upon a lipid load in $\mathrm{HF} / \mathrm{HF}$ mice. Both groups were subjected to an oral bolus of olive oil and determined postprandial TG plasma concentrations, which were much higher in the HF/HF group compared to LF/HF group $(6,753 \pm 2,213$ vs. $14,367 \pm 1,978 \mathrm{mmol} \mathrm{l}^{-1} \mathrm{~min}^{-1}, P=0.01$, Figure 6). The contribution of DNL to the hepatic lipid content, traced by ${ }^{2} \mathrm{H}_{2} \mathrm{O}$, was also determined and tended to be higher in the $\mathrm{HF} / \mathrm{HF}$ group (LF/HF vs. HF/HF: $4.24 \% \pm 0.82 \%$ vs. $7.59 \% \pm 1.38 \%, P=0.06$, Figure $5 \mathrm{C}$ ).

\section{Expression of LPL and modulators of LPL activity}

The reduced dietary lipid retention in the liver can be due to a reduced capacity of the liver to take up dietary lipids or to a reduced clearance in LPL-rich tissue such as adipose tissue. Therefore, we investigated expression of genes involved in these processes in liver and adipose tissue. No difference in hepatic Angtpl4, Angptl3,

\section{TABLE 1 Basic characteristics}

\begin{tabular}{|c|c|c|}
\hline & LF/HF & HF/HF \\
\hline Body weight (g) & $25.48 \pm 0.66$ & $27.28 \pm 0.70 \S$ \\
\hline Heart weight $(\mathrm{g})$ & $0.19 \pm 0.01$ & $0.18 \pm 0.01$ \\
\hline Liver weight (g) & $0.96 \pm 0.02$ & $0.94 \pm 0.06$ \\
\hline WAT weight $(\mathrm{g})$ & $0.77 \pm 0.08$ & $1.00 \pm 0.11$ \\
\hline Plasma TG $\left(\mathrm{mmol} \mathrm{I}^{-1}\right)$ & $0.86 \pm 0.07$ & $0.82 \pm 0.05$ \\
\hline Plasma NEFA (mmol $\left.{ }^{-1}\right)$ & $0.40 \pm 0.03$ & $0.49 \pm 0.07$ \\
\hline Plasma glucose (mmol $\left.\mathrm{I}^{-1}\right)$ & $14.0 \pm 0.8$ & $13.4 \pm 0.6$ \\
\hline Insulin $\left(\mathrm{pmol} \mathrm{I} \mathrm{I}^{-1}\right)$ & $120 \pm 8$ & $135 \pm 14$ \\
\hline HOMA-IR & $10.4 \pm 0.9$ & $10.9 \pm 1.1$ \\
\hline
\end{tabular}

$\overline{\text { Results are expressed as means } \pm \text { SEM for } 11 \mathrm{LF} / \mathrm{HF} \text { mice and } 11 \mathrm{HF} / \mathrm{HF} \text { mice }}$ from group 1. WAT, white adipose tissue; TG, triglycerides; NEFA, nonesterified fatty acids; HOMA-IR, Homeostasis Model Assessment-estimated Insulin Resistance, with $\S$ indicating a trend $(\S=P \leq 0.1)$ between the groups .
ApoE, and ApoC3 mRNA expression levels was found between LF/ $\mathrm{HF}$ and $\mathrm{HF} / \mathrm{HF}$ mice. Hepatic lipase showed a trend towards lower expression in mice exposed early to the HF diet compared to control mice (HF/HF vs. LF/HF: $0.89 \pm 0.08$ vs. $1.08 \pm 0.06, P=0.08$ ). The expression of LPL, Angtpl4, Gpihbp1 and PPAR $\gamma$ in WAT was similar in both groups (Supporting Information Table S1).

\section{Discussion}

It is generally accepted that the consumption of fat-rich diets favors the development of obesity and cardiovascular disease, often accompanied by accumulation of ectopic lipids and impaired postprandial lipid handling. An underestimated factor in the development of this phenotype may be the long-lasting influence of the exposure to an obesogenic environment during very early development (in utero and during lactation). In the present study we investigated whether exposure to an obesogenic HF diet increases the susceptibility for lipotoxic effects in the next generation. We focused on the effect on glucose tolerance, visceral, hepatic, and cardiac fat, and cardiac function. Mitochondrial function was also determined and effects on postprandial lipid handling were investigated.

We describe for the first time that exposure to a HF diet resulted in major disturbances in dietary lipid handling in offspring with increased postprandial plasma TG concentrations. Because it is well established that postprandial hypertriglyceridemia is a risk factor for cardiovascular disease (21), exposure to a HF diet during early development may be an important risk factor for morbidity and mortality later in life. It is important to note that fasted TG plasma concentrations were similar in both groups, showing the added value of postprandial plasma sampling in investigating metabolic disturbances.

HF feeding resulted in an altered pattern of ectopic fat storage with a tendency for reduced hepatic lipid content and significantly increased cardiac lipid content in offspring at week 15 of age. In general, elevated hepatic lipid content is recognized to be a 

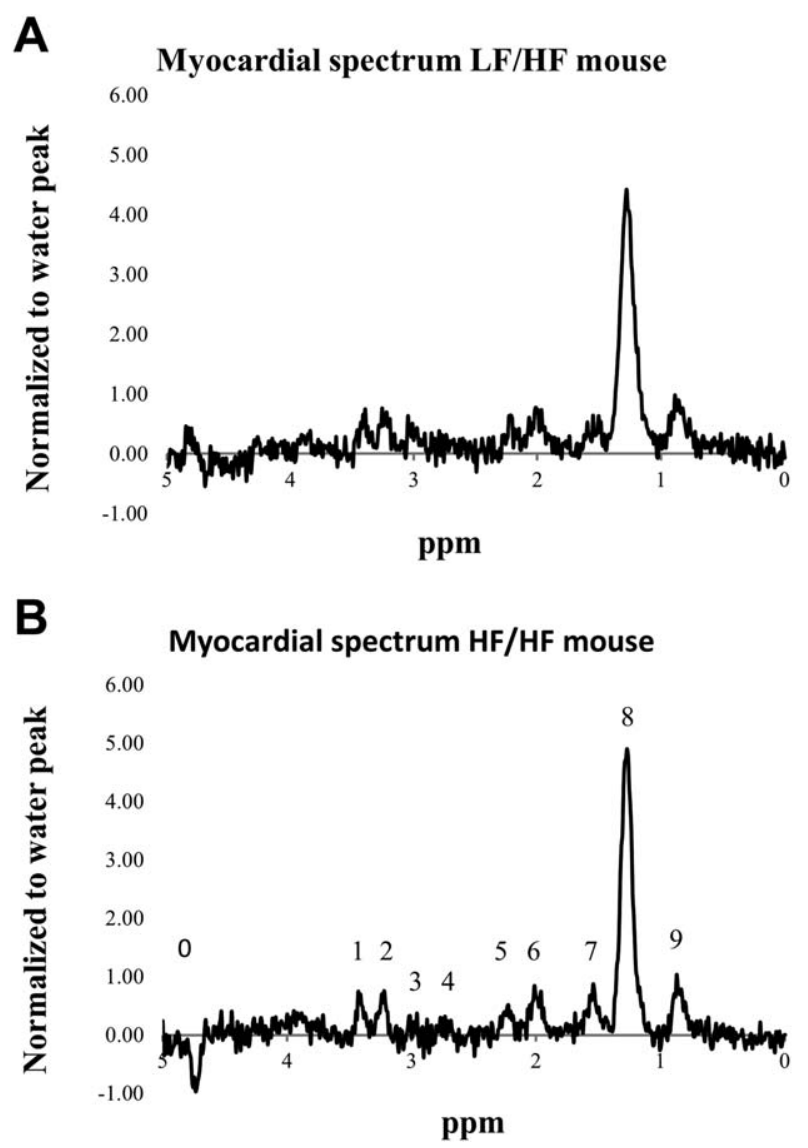

C

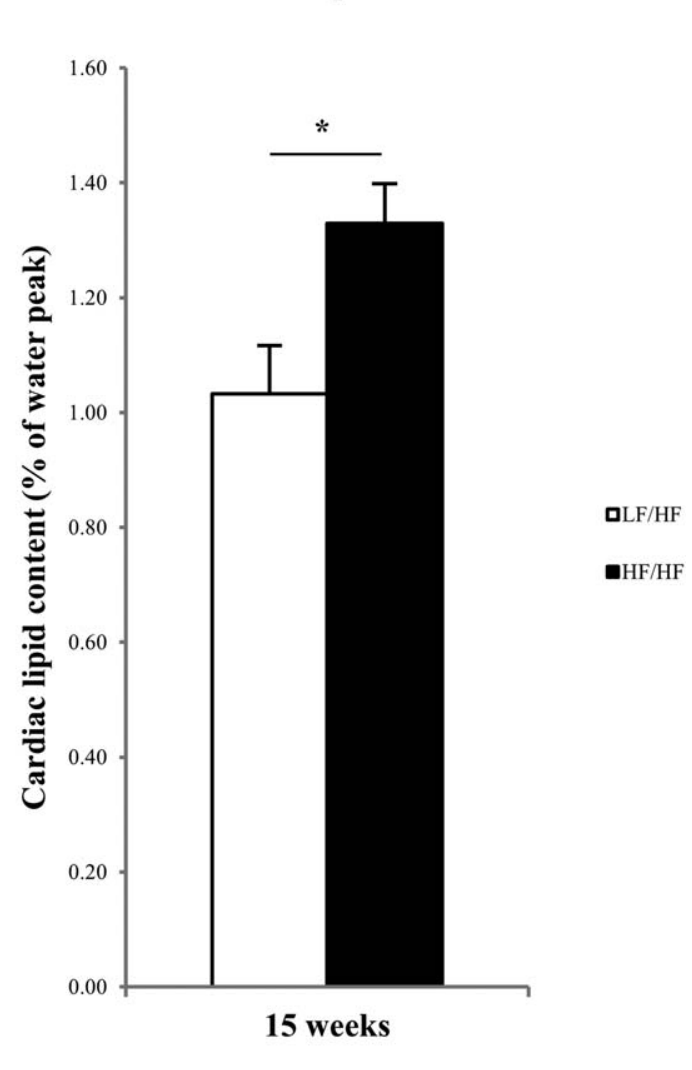

Figure 3 Representative myocardial ${ }^{1} \mathrm{H}-\mathrm{MR}$ spectrum obtained from (A) a LF/HF mouse and (B) a HF/HF mouse. Metabolite peaks were assigned as described previously (19,20). 0. residual (suppressed) water signal, 4.7 ppm; 1. taurine, 3.38 ppm; 2. carnitine, 3.21 ppm; 3. crea-

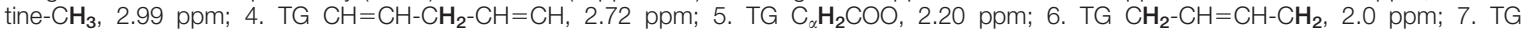
$\mathrm{C}_{\beta} \mathrm{H}_{2} \mathrm{CH}_{2} \mathrm{COO}, 1.55 \mathrm{ppm}$; 8. TG - $\left(\mathrm{CH}_{2}\right)_{n^{-}}, 1.26 \mathrm{ppm}$; and 9. TG- $\mathrm{CH}_{3}, 0.85 \mathrm{ppm}$. (C) Mean \pm SEM myocardial lipid content of mice. Significant differences between the dietary groups are indicated with ${ }^{*} P \leq 0.05$.

determinant in the development of insulin resistance and diabetes, and a reduced liver fat content would be considered a beneficial adaption. However, the reduction in hepatic fat was associated with a disturbed TG clearance and severely decreased hepatic lipid retention from a meal in the HF/HF group, which is probably the underlying reason for the low liver fat content in the current study. Consequently, a low liver fat content is most likely a reflection of disturbances in postprandial TG clearance rather than a reflection of good metabolic health.

When the liver is taking up lipids in the postprandial state, next to the action of hepatic lipase, TG uptake in the liver largely depends on the clearance of chylomicron particles by LPL in adipose tissue or skeletal muscle. To investigate the origin of the impaired TG clearance, we explored mRNA expression of PPAR- $\gamma$ and LPL as well as known LPL modulators such as Angptl4, Gpihbp1 in WAT and expression of liver-specific LPL modulators (angiopoietin-like proteins Angtpl3, Angtpl4 and apolipoproteins ApoE, ApoC3) as well as hepatic lipase. We found a tendency for reduced mRNA expression of hepatic lipase in $\mathrm{HF} / \mathrm{HF}$ mice, which may partially underlie the decreased uptake of dietary lipid during a meal and may contribute to the elevated plasma TG concentrations after an oral lipid load in $\mathrm{HF} / \mathrm{HF}$ mice.
Next to these disturbances in postprandial TG clearance, the HF/HF group shows a tendency for elevated hepatic DNL. DNL is known to be elevated in animal models of NAFLD and in humans with NAFLD and may contribute to the development of a fatty liver in the long term. In a study investigating the origin of hepatic fat in non-alcoholic steatohepatitis (NASH) patients' DNL accounted for $20-30 \%$ of fatty acids in the liver (22). Future, more prolonged studies will have to investigate whether in the long term this pathway will actually outweigh the diminished dietary lipid uptake in the liver and whether this will lead to an increased hepatic fat content in the offspring of the HF-fed mice.

In addition to the postprandial hypertriglyceridemia, which represent a cardiovascular risk factor, non-invasive MR imaging revealed that early exposure to a HF diet resulted in a tendency for elevated VAT. It is known that visceral adiposity is associated with and even predicts the development of coronary heart disease, (23) hypertension (23) and type 2 diabetes (24), further suggesting that early exposure to a HF diet results in a less preferable metabolic phenotype. The fact that the fat content of the maternal diet is a strong determinant for later metabolic health is of particular relevance as the typical Western diet contains high amounts of fat and is widely consumed, also by women of child-bearing age. Future research 

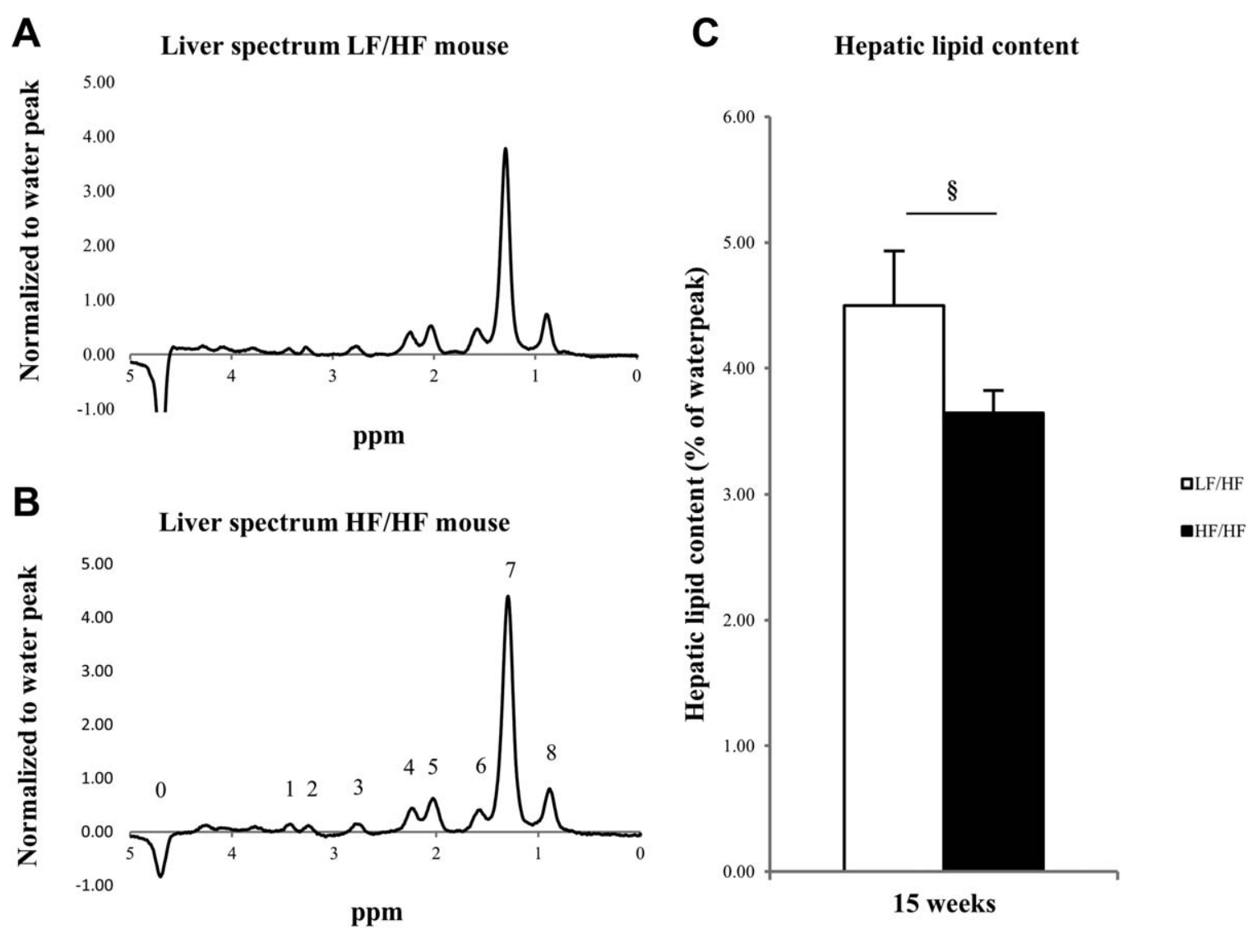

Figure 4 Representative hepatic ${ }^{1} \mathrm{H}-\mathrm{MR}$ spectrum obtained from (A) a LF/HF mouse and (B) a HF/HF mouse. Metabolite peaks were assigned as described previously $(19,20)$. 0. residual (suppressed) water signal, $4.7 \mathrm{ppm} ; 1$. taurine, $3.38 \mathrm{ppm}$; 2. carnitine, $3.21 \mathrm{ppm} ; 3$. TG $\mathrm{CH}=\mathrm{CH}-\mathrm{CH}_{2}-\mathrm{CH}=\mathrm{CH}, 2.72 \mathrm{ppm} ;$ 4. TG $\mathrm{C}_{\alpha} \mathrm{H}_{2} \mathrm{COO}$, $2.20 \mathrm{ppm}$; 5. TG $\mathrm{CH}_{2}-\mathrm{CH}=\mathrm{CH}-\mathrm{CH}_{2}, 2.0 \mathrm{ppm} ; 6 . \mathrm{TG}_{\beta} \mathrm{H}_{2} \mathrm{CH}_{2} \mathrm{COO}, 1.55 \mathrm{ppm} ; 7$. TG $-\left(\mathrm{CH}_{2}\right)_{n}-, 1.26 \mathrm{ppm}$; and 8. TG-CH, $0.85 \mathrm{ppm}$. (C) Mean \pm SEM hepatic lipid content of mice. A tendency for differences between the dietary groups is indicated with $\S P \leq 0.1$.

should further investigate the mechanism underlying the identified derangements in postprandial lipid partitioning in order to be able to prevent the development of postprandial hypertriglyceridemia induced by early exposure to a HF diet.
Contrary to the liver, cardiac lipid content was significantly increased. It is well known that cardiac tissue is able to take up circulating TG via the action of cardiac LPL. Therefore, unlike the liver, the heart is not dependent on the clearance of chylomicrons

TABLE 2 Hepatic and cardiac mitochondrial respiration levels [pmol $\left(\mathrm{s} \times \mathrm{mg}^{-1}\right)^{-1}$ ]

\begin{tabular}{|c|c|c|c|c|c|}
\hline Liver & LF/HF & $\mathrm{HF} / \mathrm{HF}$ & Heart & LF/HF & $\mathrm{HF} / \mathrm{HF}$ \\
\hline \multicolumn{3}{|c|}{ Glutamate-supported respiration } & \multicolumn{3}{|c|}{ Pyruvate-supported respiration } \\
\hline State 3 & $1124.51 \pm 95.52$ & $901.76 \pm 40.69 *$ & State 3 & $3502.23 \pm 355.07$ & $3649.58 \pm 222.57$ \\
\hline RCR & $4.46 \pm 0.22$ & $4.24 \pm 0.23$ & RCR & $5.17 \pm 0.34$ & $5.30 \pm 0.26$ \\
\hline \multicolumn{3}{|c|}{ PalmitoylCoA + carnitine-supported respiration } & \multicolumn{3}{|c|}{ PalmitoylCoA+carnitine-supported respiration } \\
\hline RCR & $2.28 \pm 0.22$ & $2.46 \pm 0.20$ & RCR & $5.03 \pm 0.60$ & $5.83 \pm 0.46$ \\
\hline
\end{tabular}

Results are expressed as means \pm SEM for 11 LF/HF mice and 11 HF/HF mice. ADP-stimulated (state 3 ) respiration was induced by the addition of ADP; state 4 respira-

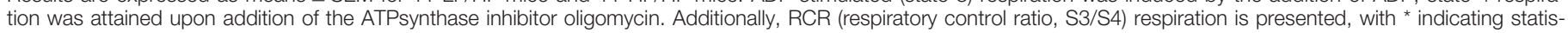
tical significance $\left({ }^{*}=P \leq 0.05\right)$ between the groups. 


\section{$\left[\mathrm{U}-{ }^{13} \mathrm{C}\right]$ lipid absorption in} heart

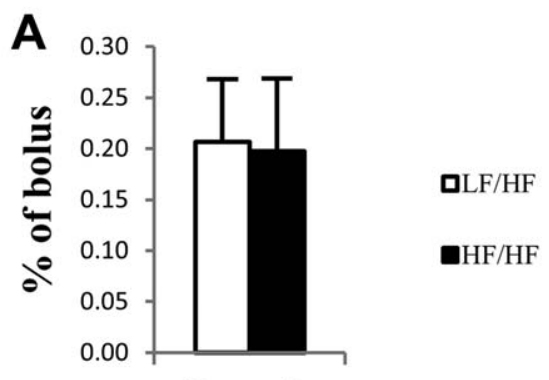

12 weeks

\section{$\left[\mathrm{U}-{ }^{13} \mathrm{C}\right]$ lipid absorption in liver}

\section{B}

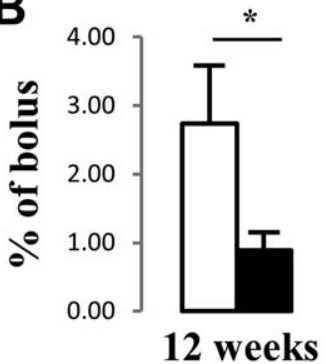

Contribution of DNL to hepatic TG content

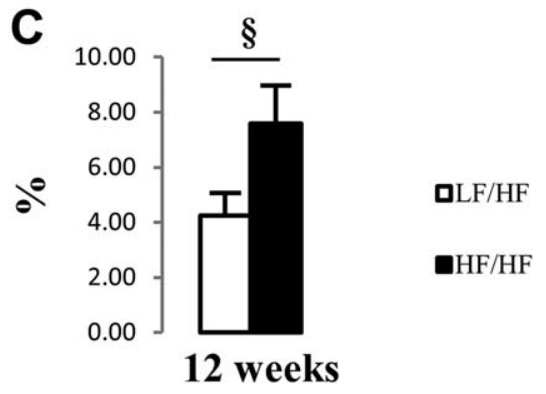

Figure 5 Mean \pm SEM of $(\mathbf{A})$ cardiac and $(\mathbf{B})$ hepatic $\left[\mathrm{U}^{13} \mathrm{C}\right]$ lipid absorption and contribution of de novo lipogenesis to hepatic TG content. No difference in cardiac lipid absorption after a meal was found, but HF/ HF mice showed significantly reduced hepatic lipid absorption after a meal $(P=0.04)$ compared to the LF/ $\mathrm{HF}$ at 12 weeks of age. (C) A trend $(P=0.06)$ for elevated contribution of DNL to hepatic TG content was found in the HF/HF group compared to the LF/HF group. Significant differences between the dietary groups are indicated with $\S P \leq 0.1$ and ${ }^{*} P \leq 0.05$.

A

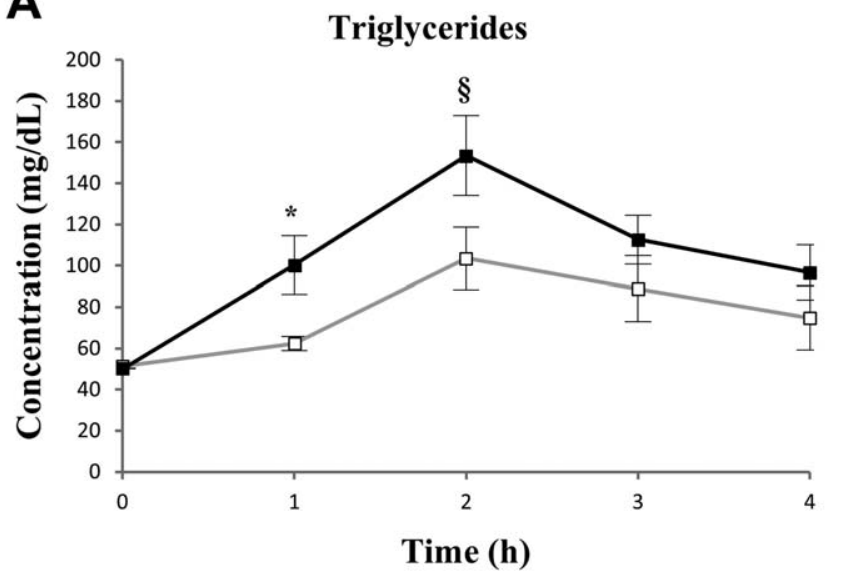

B

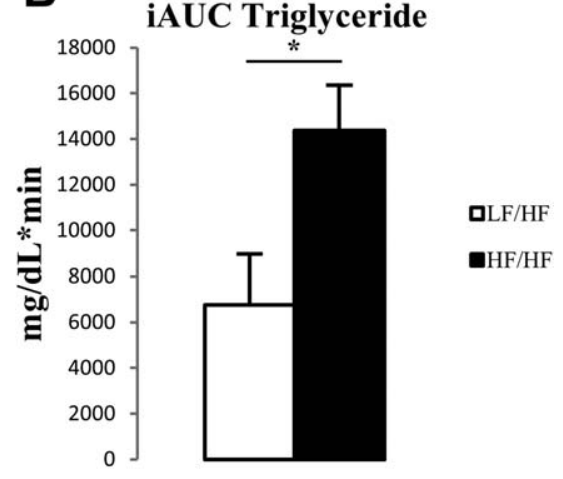

Figure 6 (A) One hour after administration of the bolus, a significant difference in plasma TG concentrations was found between the $\mathrm{HF} / \mathrm{HF}$ and LF/HF group during the TG tolerance test, performed at 12 weeks of age. (B) Incremental area under the curve (iAUC) is significantly higher $(P=0.01)$ in the $\mathrm{HF} / \mathrm{HF}$ mice compared to the LF/HF mice. Significant differences between the dietary groups are indicated with $\$ P \leq 0.1$ and ${ }^{*} P \leq 0.05$; means \pm SEM are shown. 
by other LPL-rich tissues (like skeletal muscle and adipose tissue) for TG uptake. The increased cardiac lipid content thus most likely is due to the elevated plasma TG levels observed postprandially. Moreover, it has been suggested that cardiac lipid accumulation may hamper cardiac function by so-called lipotoxic mechanisms (25). However, lipid accumulation in tissue does not necessarily lead to lipotoxicity and tissue dysfunction when the excess lipids are properly stored into lipid droplets. In this study, no compromised mitochondrial function and cardiac function were observed, despite the changes in cardiac lipid content. It is important to note that the increment in cardiac lipid content in the current study is modest when compared to genetic animal models where cardiac lipid content is often severely manipulated, which is then associated with cardiac dysfunction (26-28). The outcome of the present study is in line with earlier findings in rat (29) and men (30,31), showing that a moderate, but physiological change in cardiac fat content is not a strong determinant of cardiac function.

With the current design, we could not distinguish between the effects of maternal obesity independently from the maternal diet. Maternal obesity alone may also be a risk factor for impaired metabolic health [e.g., Ref 32]. Another study limitation is that the measurements were limited to male offspring during young adulthood and future studies will have to determine the effects in female mice and investigate the longer term effects.

In summary, early exposure to a HF diet caused yet unrecognized adaptations resulting in delayed postprandial TG clearance, imposing an increased cardiovascular risk on offspring of HF-fed mice. Impaired TG clearance may in turn be underlying the modest hepatic lipid retention from a meal in the HF/HF mice, resulting in the initially low hepatic fat content, and at the same time, the high postprandial TG levels may favor cardiac lipid accumulation. Future studies are needed to investigate the longer term effects. The stimulation of DNL and visceral fat storage let us anticipate that on the longer term, hepatic fat content will be increased in the group of early HF exposure. Other studies on prenatal HF exposure have often reported elevated hepatic fat content. Future studies are needed to confirm these mechanisms in the human setting, opening new avenues to combat postprandial hypertriglyceridemia caused by early HF exposure. $\mathrm{O}$

\section{(c) 2015 The Obesity Society}

\section{References}

1. World Health Organization (WHO). World Health Statistics 2012. World Health Organization (WHO): Geneva, Switzerland, 2012.

2. Deckelbaum RJ, Williams CL. Childhood obesity: the health issue. Obes Res 2001; 9(Suppl 4):239S-243S.

3. Surkan PJ, Hsieh CC, Johansson AL, Dickman PW, Cnattingius S. Reasons for increasing trends in large for gestational age births. Obstet Gynecol 2004;104:720726.

4. Catalano PM, Presley L, Minium J, Hauguel-de Mouzon S. Fetuses of obese mothers develop insulin resistance in utero. Diabetes Care 2009;32:1076-1080.

5. Reynolds RM, Osmond C, Phillips DI, Godfrey KM. Maternal BMI, parity, and pregnancy weight gain: influences on offspring adiposity in young adulthood. J Clin Endocrinol Metab 2010;95:5365-5369.

6. Boney CM, Verma A, Tucker R, Vohr BR. Metabolic syndrome in childhood: association with birth weight, maternal obesity, and gestational diabetes mellitus. Pediatrics 2005; 115:e290-e296.

7. Mills JL, Troendle J, Conley MR, Carter T, Druschel CM. Maternal obesity and congenital heart defects: a population-based study. Am J Clin Nutr 2010;91:15431549.
8. McCurdy CE, Bishop JM, Williams SM, et al. Maternal high-fat diet triggers lipotoxicity in the fetal livers of nonhuman primates. J Clin Invest 2009;119:323335.

9. Bruce KD, Cagampang FR, Argenton M, et al. Maternal high-fat feeding primes steatohepatitis in adult mice offspring, involving mitochondrial dysfunction and altered lipogenesis gene expression. Hepatology 2009;50:1796-1808.

10. Rorden C, Brett M. Stereotaxic display of brain lesions. Behav Neurol 2000;12:191200.

11. Vanhamme L, van den Boogaart A, Van Huffel S. Improved method for accurate and efficient quantification of MRS data with use of prior knowledge. J Magn Reson 1997; 129:35-43.

12. van de Weijer T, van Ewijk PA, Zandbergen HR, et al. Geometrical models for cardiac MRI in rodents: comparison of quantification of left ventricular volumes and function by various geometrical models with a full-volume MRI data set in rodents. Am J Physiol Heart Circ Physiol 2012;302:H709-H715.

13. Paglialunga $\mathrm{S}$, van Bree $\mathrm{B}$, Bosma $\mathrm{M}$, et al. Targeting of mitochondrial reactive oxygen species production does not avert lipid-induced insulin resistance in muscle tissue from mice. Diabetologia 2012;55:2759-2768.

14. Schwartz DM, Wolins NE. A simple and rapid method to assay triacylglycerol in cells and tissues. J Lipid Res 2007;48:2514-2520.

15. Hoeks J, Briede JJ, de Vogel J, et al. Mitochondrial function, content and ROS production in rat skeletal muscle: effect of high-fat feeding. FEBS Lett 2008;582: 510-516.

16. Sparks LM, Xie H, Koza RA, et al. A high-fat diet coordinately downregulates genes required for mitochondrial oxidative phosphorylation in skeletal muscle. Diabetes 2005;54:1926-1933.

17. Nunes PM, Wright AJ, Veltien A, et al. Dietary lipids do not contribute to the higher hepatic triglyceride levels of fructose- compared to glucose-fed mice. FASEB J 2014;28:1988-1997.

18. Delgado TC, Pinheiro D, Caldeira M, et al. Sources of hepatic triglyceride accumulation during high-fat feeding in the healthy rat. NMR Biomed 2009;22:310317.

19. Schneider JE, Tyler DJ, ten Hove M, et al. In vivo cardiac 1 H-MRS in the mouse. Magn Reson Med 2004;52:1029-1035.

20. Griffin JL, Williams HJ, Sang E, Nicholson JK. Abnormal lipid profile of dystrophic cardiac tissue as demonstrated by one- and two-dimensional magic-angle spinning (1)H NMR spectroscopy. Magn Reson Med 2001;46:249-255.

21. Nordestgaard BG, Benn M, Schnohr P, Tybjaerg-Hansen A. Non-fasting triglycerides and risk of for myocardial infarction and death among women and men. Ugeskr Laeger 2007;169:3865-3868.

22. Donnelly KL, Smith CI, Schwarzenberg SJ, Jessurun J, Boldt MD, Parks EJ. Sources of fatty acids stored in liver and secreted via lipoproteins in patients with nonalcoholic fatty liver disease. J Clin Invest 2005;115:1343-1351.

23. Fujimoto WY, Bergstrom RW, Boyko EJ, et al. Visceral adiposity and incident coronary heart disease in Japanese-American men. The 10-year follow-up results of the Seattle Japanese-American Community Diabetes Study. Diabetes Care 1999;22: 1808-1812.

24. Boyko EJ, Fujimoto WY, Leonetti DL, Newell-Morris L. Visceral adiposity and risk of type 2 diabetes: a prospective study among Japanese Americans. Diabetes Care 2000;23:465-471.

25. Kankaanpaa M, Lehto HR, Parkka JP, et al. Myocardial triglyceride content and epicardial fat mass in human obesity: relationship to left ventricular function and serum free fatty acid levels. J Clin Endocrinol Metab 2006;91:4689-4695.

26. Finck BN, Han $X$, Courtois $M$, et al. A critical role for PPARalpha-mediated lipotoxicity in the pathogenesis of diabetic cardiomyopathy: modulation by dietary fat content. Proc Natl Acad Sci USA 2003;100:1226-1231.

27. Haemmerle G, Lass A, Zimmermann R, et al. Defective lipolysis and altered energy metabolism in mice lacking adipose triglyceride lipase. Science 2006;312:734-737.

28. Chiu HC, Kovacs A, Ford DA, et al. A novel mouse model of lipotoxic cardiomyopathy. J Clin Invest 2001;107:813-822.

29. Axelsen LN, Lademann JB, Petersen JS, et al. Cardiac and metabolic changes in long-term high fructose-fat fed rats with severe obesity and extensive intramyocardial lipid accumulation. Am J Physiol Regul Integr Comp Physiol 2010; 298:R1560-R1570.

30. Bilet L, van de Weijer T, Hesselink MK, et al. Exercise-induced modulation of cardiac lipid content in healthy lean young men. Basic Res Cardiol 2011;106:307315.

31. Schrauwen-Hinderling VB, Meex RC, Hesselink MK, et al. Cardiac lipid content is unresponsive to a physical activity training intervention in type 2 diabetic patients, despite improved ejection fraction. Cardiovasc Diabetol 2011;10:47.

32. Nathanielsz PW, Poston L, Taylor PD. In utero exposure to maternal obesity and diabetes: animal models that identify and characterize implications for future health. Obstet Gynecol Clin North Am 2007;34:201-212, vii-viii. 